\title{
AUTUMN RECORDS OF PARASITIC JAEGERS IN CENTRAL ALBERTA
}

\author{
by Dick Dekker, 3819 - 112A Street, Edmonton
}

At Beaverhill Lake, 40 miles east of Edmontion, Alberta, during the late summer and early fall of 1964, 1966, and 1967, I made 32 observations of jaegers. Nearly all these birds flew close to the shore of the lake and showed little or no fear of humans, hence it was often possible to identify them with certainty as Parasitic Jaegers (Stercorarius parasiticus). Except for one bird whose tail feathers were evidently broken off (September 21), their elongated central tail feathers were pointed and about two inches long. All identified birds were adults of the light phase, and often a partial breast band was noticeable.

Jaegars were seen on two of five observation days in 1964; on none of five days in 1965; on one of 12 days in 1966; and on nine of 20 days in 1967. In 1964, doubles were seen twice on Augusit 29; single birds were seen twice, and a couple, on September 20. In 1966, one was seen on September 27. In 1967, one was seen on August 27; a double on September 8; a single, a double, and four at once, on September 9 ; one on September 12; singles three times on September 13; singles twice on September 16; singles three times on September 21; one on September 30 ; and singles three times on October 8.

In 1967 especially, jaegers appeared to be of regular occurrence. As the weather was exceptionally fine during August and September several birds may have stayed in the area for a period of time, causing duplication of observations. On the other hand, seven birds seen on September 9 were believed to be different individuals : a single bird, and later a pair, were observed hunting along the shore; a group of four was leisurely soaring and moving away from the lake in a southerly direction.

By far the most interesting obser- vations were those of their powers of flight. A jaeger can fly as leisurely as a gull, but when his predatory instincts are aroused, his wingbeats become as fast and vigorous as a falcon's. Waders and waterfowl react to his appearance as they do to a hunting peregrine: waders go up in tight flocks; ducks choose the safety of the water; coots and the smaller ducks dive with a splash when they find themselves directly in the line of flight of an approaching jaeger, skimming the lake's surface.

At one time a jaeger made a pass at an immature Herring Gull, but the latter turned around and chased the jaeger. The smaller gulls, such as Ring-billed and Bonaparte's, however, appear terrified when a jaeger singles them out. Apparently they sense it from a distance. Ring-billed Gulls did not even attempt to escape, but were seen to fly around erratically, screaming. Ofter the jaeger harassed a gull in vain; at any rate no disgorging of food was noticed. However, the last jaeger seen (October 8, 1967), which pursued a gull close to the observer, was rewarded with a shower of food particles. The jaeger dived and picked up the biggest chunk in mid-air. Once two jaegers were battling a Ringbilled Gull when one of the two apparently got so excited that he grabbed the gull twice. The second time both jaeger and gull fell into the water, where they separated. Jaegers also chase birds other than gulls. Sitting behind the observation blind of the Edmonton Bird Club on the south shore of Beaverhill Lake, Ludo Bogaert and the author saw a jaeger pursue a Marbled Godwit, which used the blind as a cover to escape. It shot past at arm's length, while the jaeger passed overhead in a rush of wings.

Some jaegers seem to specialize in the hunting of small waders. They 
give chase with apparent intent to kill. This was observed on several occasions. Always the jaegers hunted in pairs, flying low at terrific speed. Waders rose in front of them, and one of the little birds was singled out and pursued by both jaegers. Often it was so hard pressed that it was forced to take cover. One was seen to describe a great circle over the lake and finally plunge into a stand of reeds. The jaegers did not pause for a second but immediately climbed at a great pace towards a group of high-flying waders. They concentrated their efforts on a bird that left the group and made for the reeds. It lost altitude rapidly, but before it reached cover pursued and pursuer became one. The distance was too great to see clearly what took place, but it appeared that the sandpiper was caught. While its mate stayed in the air, the lucky jaeger perched on the ground for a minute, long enough to take care of its prize, which likely was swallowed whole.

To see the two dark-winged, whitebellied birds race low over the mud- flats and the water, is an exciting spectacle. They surely are faster than the merlin, and possibly also swifter than the peregrine. In hunting so adroit a flyer as a sandpiper they have a great advantage over the falcons. Instead of stooping at their prospective prey and often overshooting the mark, they are able to follow all its movements. However, as is the case with both merlin and peregrine, by far the greater number of birds chased finally escape, either because the wader makes a smart move and outdistances its pursuer, or because the latter simply gives up and goes looking for an easier target.

In spite of many days of watching in April and May, when countless waders make a stop-over at Beaverhill Lake on their way north, no jaegers have been sighted there during that time. Fall migration through Alberta seems to be fairly regular, however, and may cover a wide front. During September of 1960 I saw a jaeger near Morley, in the foothills west of Calgary.

\section{FIRST RECORD OF RUFF FOR ALBERTA}

\section{by Bruce Jones and M. T. Myres}

\section{Museum of Zoology, Department of Biology, University of Calgary}

On May 15, 1967, B. Jones observed four birds that he was at first unable to identify. They were swimming on a slough two miles southeast of Janet, A lberta $\left(50^{\circ} 58^{\prime} 30^{\prime \prime} \mathrm{N}, 113^{\circ} 50^{\prime} 30^{\prime \prime}\right.$ W), about 10 miles east of Calgary. He collected one. Only then did he realize that he had seen four Ruffs (Philomachus pugnax), or more properly two Ruffs and two Reeves.

The bird collected was a male with testis measurement $7 \times 13 \mathrm{~mm}$. indicating a trend to breeding condition. The plumage approximates most closely the type $\mathrm{B}_{2}$ described by Witherby et al (1940). The occipital tufts are black with a purple gloss. The pectoral ruff is white with some grey spots. The underparts are white. The back is pale buff and grey-brown with many feathers having a purple gloss. The skin is No. 145 in the Museum of Zoology of the Department of Biology, University of Calgary.

The four birds seen exhibited somewhat unusual behaviour in that they were swimming on the surface of a slough that was between eight inches and two feet deep at that point, some 15 yards from the shore. They swam in an area of approximately 40 square feet, picking at the surface and occasionally dipping their heads beneath it. During 10 minutes of observation the two males twice suddenly chased each other vigorously in a circle around a fence-post standing in the water. While doing so they displayed their ruffs and quivered their wings for a few seconds. After each occa- 